\title{
Is There a Balance Problem in Hypermobile Patients with Fibromyalgia?
}

\author{
Hipermobil Fibromiyalji Hastalarında Denge Sorunu Var mı?
}

\author{
Yasemin ULUS, Yeşim AKYOL, Berna TANDER, Dilek DURMUŞ, Ayhan BİLGİCİ, Ömer KURU \\ Department of Physical Medicine and Rehabilitation, Medical Faculty of Ondokuz Mayıs University, Samsun, Turkey
}

\begin{abstract}
Objectives: This study aims to investigate the relationship between hypermobility and balance problem and the possible effect of this relationship on fall frequency in patients with fibromyalgia syndrome (FMS).
\end{abstract}

Patients and methods: Sixty female patients with FMS and 30 healthy female controls were included in the study. The mean age of all participants was $41.8 \pm 9.9$ years with a range of 22 to 62 years. The patients were divided into three groups: group 1 included FMS patients with hypermobility, group 2 included FMS patients without hypermobility, and group 3 included controls. Outcome measures for the FMS patients included disease duration, pain as assessed by the Visual Analog Scale (VAS), disease activity as assessed by the Fibromyalgia Impact Questionnaire (FIQ). The number of falls, functional performance as assessed by six-minute walk distance (6MWD) test, balance as assessed by the one-legged balance test with open eyes in conjunction with the Berg Balance Scale (BBS), and hypermobility as assessed by the Beighton criteria were evaluated in all participants.

Results: There was no statistically significant difference between groups 1 and 2 in terms of duration of disease, VAS pain, FIQ, or number of falls ( $p>0.05$ ). The number of falls was significantly different in group 1 than group $3(p<0.05)$. There was no significant difference among the groups in the 6MWD test $(p>0.05)$. The mean one-leg balance testing time and the mean BBS score were significantly different in the three groups $(p<0.05)$. No significant correlation was found among the pain and balance tests and the number of falls $(p>0.05)$. Hypermobility had a significant effect on the balance tests $(p<0.001)$.

Conclusion: The balance problem was found to be significantly higher in FMS patients with hypermobility than in those without hypermobility and in the healthy controls. This situation needs to be considered when clinically assessing FMS patients, as well as the patients should be informed, and appropriate measurements should be performed.

Key words: Balance; fall; fibromyalgia syndrome; hypermobility.
Amaç: Bu çalışmada fibromiyalji sendromu (FS) olan hastalarda hipermobilite ile denge sorunu arasındaki ilişki ve bu ilişkinin düşme sıklığı üzerine etkisi araştırıldı.

Hastalar ve yöntemler: Altmış FS'li ve 30 sağlıklı kadın kontrol çalışmaya dahil edildi. Tüm katılımcıların ortalama yaşı 41.8ะ9.9 yıl olup, yaşları 22-62 yıl arasında idi. Hastalar üç gruba ayrıldı: grup 1 hipermobilitesi olan FS'li hastalardan, grup 2 hipermobilitesi olmayan FS'li hastalardan ve grup 3 kontrollerden oluşuyordu. Fibromiyalji sendromu olan hastaların sonuç ölçümleri; hastalarda hastalık süresi, görsel analog ölçeği (GAÖ) ile değerlendirildiği üzere ağrı, Fibromyalji Etki Anketli (FEA) ile değerlendirildiği üzere hastalık aktivitesini içermekteydi. Tüm katılımcılarda düşme sayısı, altı dakika yürüme testi (6DYT) ile fonksiyonel performans, gözler açıkken tek bacak denge testi ve Berg Denge Skalası (BDS) ile denge ve Beighton kriterleri ile hipermobilite değerlendirildi.

Bulgular: Grup 1 ve 2 arasında hastalık süresi, GAS ağrı, FEA ve düşme sayısı açısından istatistiksel olarak anlamlı fark yoktu ( $p>0.05)$. Düşme sayısı grup 1'de grup 3'den anlamlı olarak farklıydı $(p<0.05)$. Altı dakika yürüme testi gruplar arasında anlamlı olarak farklı değildi $(p>0.05)$. Ortalama tek bacak denge testi zamanı ve ortalama BDS skoru her üç grupta anlamlı olarak farklıydı $(p<0.05)$. Ağrı, denge testleri ve düşme sayısı arasında anlamlı ilişki saptanmadı ( $p>0.05)$. Hipermobilitenin denge testleri üzerine anlamlı etkisi saptandı $(p<0.001)$.

Sonuç: Hipermobilitesi olan FS'li hastalarda, hipermobilitesi olmayan FS'li hastalara ve sağlıklı kontrollere kıyasla, denge sorunu anlamlı olarak yüksek bulundu. Bu durum FS'li hastaların değerlendirilmesinde göz önünde bulundurulmalı, hastalar bilgilendirilmeli ve gerekli ölçümler yapılmalıdır.

Anahtar sözcükler: Denge; düşme; fibromiyalji sendromu; hipermobilite.

Received: May 28, 2012 Accepted: July 25, 2012

Correspondence: Yasemin Ulus, M.D. Ondokuz Mayıs Üniversitesi Tıp Fakültesi, Fiziksel Tıp ve Rehabilitasyon Anabilim Dalı, 55139 Kurupelit, Samsun, Turkey. Tel: +90 362 - 3121919 e-mail: yaseminulus@gmail.com 
Fibromyalgia syndrome (FMS) is a chronic disorder that is characterized by diffuse musculoskeletal pain, sleep disturbance, fatigue, stiffness, and the presence of multiple tender points. ${ }^{[1,2]}$ Hypermobility denotes an increased range of joint movement. The (benign) joint hypermobility syndrome, or hypermobility syndrome (HMS), is defined as the occurrence of musculoskeletal symptoms in hypermobile subjects in the absence of demonstrable systemic rheumatological disease. ${ }^{[3]}$ Kirk et al. ${ }^{[4]}$ first described HMS as a pathological condition characterized by joint hypermobility and musculoskeletal complaints. It is a common disorder and occurs more often in females. ${ }^{[3]}$

Balance is a complex function of numerous neuromuscular processes that include sensory, motor, and integrated components. ${ }^{[5]}$ Balance control is a highly specific proprioception in the performance of daily activities and is essential in all postures and situations, both static (maintaining an upright posture) and dynamic (in locomotion). ${ }^{[5]}$ A lack of proprioception seems to be a prominent feature in HMS, ${ }^{[6,7]}$ and reduced balance has been described for subjects with this disorder. ${ }^{[8]}$

The coexistence of HMS and FMS has been shown in previous studies in which it was suggested that hypermobility may play a prominent role in the pathogenesis of pain in women with FMS. ${ }^{[9-12]}$ It has also been reported that FMS is associated with balance problems and increased fall frequency ${ }^{[13]}$ To the best of our knowledge, at the present time no published reports have specifically reported the relationship between hypermobility and balance in patients with FMS. Hence, the aim of this study was to determine the extent of this possible relationship and determine its impact on fall frequency in patients with FMS.

\section{PATIENTS AND METHODS}

The study was conducted at the Department of Physical Medicine and Rehabilitation of the Medical Faculty of "Ondokuz Mayıs University", and the local ethics committee approved the study protocol. Sixty females who met the 1990 American College of Rheumatology (ACR) criteria for $\mathrm{FMS}^{[1]}$ and 30 healthy female controls were enrolled in the study. All participants were between 22 and 62 years old and had a mean age of $41.8 \pm 9.9$ years. Patients who had undergone surgery or those who had suffered from a medical condition within the past year that would cause balance deficits (e.g., stroke, knee replacement, or vestibular disorder) were excluded from the study.
All participants were questioned about their age, gender, body mass index (BMI), working status, educational level, medical comorbidities, and current medications. The disease duration of the patients was also reported. All participants were asked to recall how many falls they had suffered in the last six months, with falls being defined as unintentionally coming to rest on the floor or a low surface (bed, chair, etc.). ${ }^{[13]}$

In this study, the participants were divided into three groups: group 1 was composed of FMS patients with hypermobility, group 2 was comprised of FMS patients without hypermobility, and group 3 was the control group.

\section{Clinical assessments}

The following outcome measures were performed by the same researcher:

\section{Measurement of pain severity}

The global pain of the patients was assessed by a $10 \mathrm{~cm}$ visual analog scale (VAS) in which a score of 0 indicated no pain, and a score of 10 indicated very severe pain. ${ }^{[14]}$

\section{Fibromyalgia impact questionnaire (FIQ)}

The FIQ is widely used in patients with FMS to evaluate both the clinical severity of the disease and the efficacy of different treatments. ${ }^{[15]}$ It is a selfadministered questionnaire and consists of the VAS along with questions regarding limitations of daily living activities over the previous week. The total score ranges from 0 to 80 , and a higher score indicates a more negative impact. It was found to be a reliable and valid instrument with Turkish female FMS patients. ${ }^{[16]}$

\section{Functional performance}

The six-minute walk distance (6MWD) test was used as a objective assessment of functional performance and endurance. ${ }^{[17]}$ Subjects completed this test on a 42.6 meter walkway. They were given the same standard verbal instructions before each test and told to walk their maximum distance in a six-minute period. The total distance covered in meters during the 6MWD was used as the score for each session.

\section{One-legged balance test with eyes open}

Static balance of the participants was evaluated by a one-legged balance test with eyes open. Each participant was asked to stand on her preferred leg with her arms folded across the chest. One foot was then raised while bending the knees at about a 45 
degree angle, and a stopwatch was started. The test was performed for 30 seconds. If any use of the arms or the contralateral leg was used for support, the stopwatch was stopped, and the time was noted. Three trials were allowed, and the best result was used. ${ }^{[18,19]}$

\section{The berg balance scale}

The Berg Balance Scale (BBS) was originally developed for the assessment of postural control and is widely used in many fields of rehabilitation. ${ }^{[20]}$ Scores on the BBS were determined by using a five-point ordinal scale to evaluate the subjects who performed 14 functional activities. The maximum score on the BBS is 56 , and a score below 40 indicates a fall risk of nearly $100 \% .{ }^{[21]}$ The reliability and validity of the Turkish form of the BBS was performed by Şahin et al. ${ }^{[20]}$

\section{The Beighton hypermobility score}

Hypermobility was determined according to the criteria described in 1973 by Beighton et al. ${ }^{[22]}$ Patients were graded on a scale ranging from $0-9$, and a score of at least 4 indicated joint hypermobility. The Beighton hypermobility scores have been shown to have high intra- and inter-rater reliability. ${ }^{[23]}$

\section{Statistical analyses}

Statistical analyses were performed with SPSS (SPSS Inc., Chicago, Illinois, USA) version 16.0 for Windows. Descriptive data were presented as mean \pm standard deviation (SD) or (median) minimum-maximum. The Shapiro-Wilk test was used to analyze the normal distribution assumption of the quantitative outcomes, and the Kruskal-Wallis test was used to compare the three groups because the data was not normally distributed. To compare two groups, the MannWhitney $U$ test was used. We corrected for multiple comparisons using the Bonferroni adjustment, and the correlations were investigated using Spearman's correlation analysis. The sociodemographic characteristics (education, occupation) of the groups were evaluated by a chi-square test, and univariate analysis of variance (ANOVA) was used to assess the effect of hypermobility on the balance tests, $6 \mathrm{MWD}$, and the number of falls. A $p$ value of less than 0.05 was considered to be statistically significant. Sample size estimation was performed using Power Analysis and Sample Size (PASS) 2008 software. In order to have a statistical power of 0.80 and $\mathrm{p}<0.05$, data from a previous study was utilized ${ }^{[13]}$ to determine that each group required 30 subjects to detect the differences in the FIQ total score.

\section{RESULTS}

The clinical and demographic data of the subjects is given in Table 1 . There were no statistically significant differences in the sociodemographic data between the groups ( $\mathrm{p}>0.05$ ).

No statistically significant differences existed between groups 1 and 2 in terms of the duration of disease $(\mathrm{p}=0.982)$, the number of falls $(\mathrm{p}=0.868)$, the VAS pain score (0.835), and the FIQ score $(\mathrm{p}=0.515)$ (Table 1$)$.

Table 1. Comparison of the demographic and clinical data

\begin{tabular}{|c|c|c|c|c|c|c|c|c|c|c|c|c|c|}
\hline & \multicolumn{4}{|c|}{ Group $1(n=30)$} & \multicolumn{4}{|c|}{ Group $2(n=30)$} & \multicolumn{4}{|c|}{ Group $3(n=30)$} & \multirow[b]{2}{*}{$p$} \\
\hline & $\mathrm{n}$ & Mean \pm SD & Median & Min-max. & $\mathrm{n}$ & Mean \pm SD & Median & Min-max. & $\mathrm{n}$ & Mean \pm SD & Median & Min-max. & \\
\hline Age (years) & & $42.2 \pm 10.42$ & 44 & $23-58$ & & $42.43 \pm 10.52$ & 43 & $24-62$ & & $40.67 \pm 9.03$ & 42 & $22-58$ & $0.791^{*}$ \\
\hline Body mass index $\left(\mathrm{kg} / \mathrm{m}^{2}\right)$ & & $27.31 \pm 3.70$ & 28 & $21-36$ & & $27.34 \pm 5.14$ & 26 & $17-38$ & & $25.97 \pm 4.57$ & 25 & $18-35$ & $0.384^{*}$ \\
\hline \multicolumn{14}{|l|}{ Occupation } \\
\hline Housewife & 21 & & & & 23 & & & & 20 & & & & \\
\hline Working & 6 & & & & 5 & & & & 9 & & & & $N S^{* * *}$ \\
\hline Retired & 3 & & & & 2 & & & & 1 & & & & \\
\hline \multicolumn{14}{|l|}{ Education } \\
\hline Literate & 2 & & & & 1 & & & & 1 & & & & \multirow{4}{*}{$\mathrm{NS}^{* * *}$} \\
\hline Primary education & 14 & & & & 16 & & & & 11 & & & & \\
\hline Secondary education & 8 & & & & 9 & & & & 10 & & & & \\
\hline College & 6 & & & & 4 & & & & 8 & & & & \\
\hline Disease duration (months) & & $4.40 \pm 11.0$ & 3.5 & $1-10$ & & $4.67 \pm 3.96$ & 3 & $1-14$ & & - & - & - & $0.982^{* *}$ \\
\hline VAS pain score & & $8.27 \pm 0.94$ & 8 & $5-10$ & & $8 \pm 1.74$ & 9 & $5-10$ & & - & - & - & $0.835^{* *}$ \\
\hline FIQ score & & $60.5 \pm 1.40$ & 63 & $30-81$ & & $63.12 \pm 1.46$ & 61 & $32-88$ & & - & - & - & $0.515^{* *}$ \\
\hline 6MWD (m) & & $512.93 \pm 85.06$ & 532 & $360-640$ & & $501.24 \pm 84.98$ & 532 & $336-624$ & & $514.47 \pm 71.80$ & 534 & $344-620$ & $0.052^{*}$ \\
\hline One-legged balance test $(s)^{a, b, c}$ & & $15.93 \pm 8.3$ & 15 & 5-30 & & $22.83 \pm 7.84$ & 25 & $5-30$ & & $28.5 \pm 3.06$ & 30 & $20-30$ & $<0.001^{*}$ \\
\hline BBS score $\mathrm{s}^{\mathrm{a}, \mathrm{b}, \mathrm{c}}$ & & $50.63 \pm 4.2$ & 50 & $36-56$ & & $54.47 \pm 2.03$ & 56 & $50-56$ & & $55.87 \pm 0.34$ & 56 & $55-56$ & $<0.001^{*}$ \\
\hline Number of falls ${ }^{\mathrm{b}}$ & & $0.37 \pm 0.61$ & 0 & $0-2$ & & $0.30 \pm 0.46$ & 0 & $0-1$ & & $0.10 \pm 0.30$ & 0 & $0-1$ & $0.102^{*}$ \\
\hline Beighton total score $\mathrm{e}^{\mathrm{a}, \mathrm{b}}$ & & $5.07 \pm 0.36$ & 5 & $4-6$ & & $0.20 \pm 0.40$ & 0 & $0-1$ & & $0.30 \pm 0.46$ & 0 & $0-1$ & $<0.001^{*}$ \\
\hline
\end{tabular}




\begin{tabular}{|c|c|c|c|c|}
\hline & \multicolumn{4}{|c|}{ VAS pain } \\
\hline & \multicolumn{2}{|c|}{ Group 1} & \multicolumn{2}{|c|}{ Group 2} \\
\hline & $\mathrm{r}$ & $p$ & $\mathrm{r}$ & $p$ \\
\hline One-legged balance test & -0.098 & 0.607 & 0.190 & 0.315 \\
\hline Berg Balance Scale & 0.102 & 0.593 & -0.132 & 0.486 \\
\hline Number of falls & 0.056 & 0.770 & 0.035 & 0.855 \\
\hline
\end{tabular}

The number of falls was significantly different in group 1 when compared with group $3(\mathrm{p}=0.048)$, but group 2 did not differ significantly from group 3 $(\mathrm{p}=0.055)$ (Table 1). Furthermore, the 6MWD scores were not significantly different between groups 1 and 2 $(\mathrm{p}=0.523)$, groups 1 and $3(\mathrm{p}=0.082)$, and groups 2 and $3(p=0.057)$ (Table 1$)$, whereas the one-legged balance testing time was significantly different between groups 1 and $2(\mathrm{p}=0.002)$, groups 1 and 3 $(\mathrm{p}=0.003)$, and groups 2 and $3(\mathrm{p}<0.001)$ (Table 1$)$. The BBS score was also significantly different between groups 1 and $2(\mathrm{p}<0.001)$, groups 1 and $3(\mathrm{p}=0.002)$, and groups 2 and $3(\mathrm{p}<0.001)$ (Table 1$)$. Additionally, the Beighton score was significantly higher in group 2 than in group $1(\mathrm{p}<0.001)$ and group 3 $(\mathrm{p}<0.001)$, but it differed between groups 1 and 3 $(\mathrm{p}=0.375)($ Table 1$)$.

In groups 1 and 2 , there were no significant correlations when pain was compared with the balance tests and the number of falls (Table 2), and no further significant correlations were found between the number of falls and the balance tests in these two groups (Table 3).

According to univariate ANOVA, no significant effect of hypermobility was detected with regard to the number of falls $(\mathrm{p}=0.159)$ and 6MWD $(\mathrm{p}=0.825)$. On the other hand, it did significantly affect the balance tests $(\mathrm{p}<0.001)$.

\section{DISCUSSION}

Fibromyalgia syndrome is a chronic disease, and it has a wide range of symptoms, including impaired balance. $^{[13,24,25]}$ In addition, a strong association exists between FMS and hypermobility. ${ }^{[9-12]}$ Hypermobility syndrome is a systemic disorder which affects virtually all joints, and the lack of proprioception is a wellknown feature. ${ }^{[6,7]}$ Impaired joint proprioception can lead to poor postural control and balance in patients with HMS, as has been previously demonstrated by the research. ${ }^{[13,26]}$ However, a review of the literature did not reveal any studies which have evaluated balance problems in FMS patients and their association with hypermobility. Furthermore, a connection between increased fall frequency due to balance problems in FMS has been previously shown, but the relationship between hypermobility and fall history has not yet been studied.

In the present study, balance was assessed by the one-legged balance test and BBS, and groups 1 and 2 had more balance problems than group 3. Moreover, the results of the balance test with patients in group 1 revealed they were impaired compared to the patients in group 2, leading to the conclusion that hypermobility was found to be an influential variable. There is a high prevalence of falls with FMS patients, ${ }^{[27]}$ and impaired balance increases this risk. ${ }^{[28]}$ Unexpectedly, in this trial, the number of falls was not correlated with poor balance in FMS patients. Furthermore, contradictory

\begin{tabular}{|c|c|c|c|c|}
\hline & \multicolumn{4}{|c|}{ Number of falls } \\
\hline & \multicolumn{2}{|c|}{ Group 1} & \multicolumn{2}{|c|}{ Group 2} \\
\hline & $\mathrm{r}$ & $p$ & $\mathrm{r}$ & $p$ \\
\hline One-legged balance test & -0.126 & 0.506 & 0.187 & 0.470 \\
\hline Berg Balance Scale score & 0.278 & 0.138 & -0.137 & 0.321 \\
\hline
\end{tabular}


results were obtained concerning the relationship between hypermobility and fall history. The number of falls was similar in groups 1 and 2, and no difference was seen between the patients in group 2 and the healthy controls in group 3. Although the number of falls in group 1 differed from group 3, hypermobility was not found to be a predictive variable for the number of falls. Therefore, it can be suggested that FMS patients may have balance problems compared with healthy subjects and that hypermobility may have a negative effect on balance in these patients. In addition, it is known that the risk for falls increases dramatically with age. ${ }^{[29-31]}$ To clarify the impact of balance and hypermobility on fall frequency, future studies with older FMS patients should be undertaken.

Balance and postural stability during gait requires more attention, and a slow walking pace can be anticipated in patients with poor balance. In this study, functional performance as measured by the $6 \mathrm{MWD}$ test was similar in each group, and it was shown that difficulty in walking increases with aging. ${ }^{[32]}$ In this trial, the study population was middle-aged women, and it seems that hypermobility and balance problems may not affect the walking ability of middle-aged FMS patients. Although there is no established linkage between pain and hypermobility ${ }^{[10]}$ Harding and Grahame ${ }^{[33]}$ determined that $40 \%$ of patients with chronic pain reported past or present joint hypermobility. In the current study, the VAS pain scores were not statistically different between groups 1 and 2 . Thus, it can be hypothesized that hypermobility may not be the only factor in the development of pain in FMS patients. Contrary to the work of Jones et al. ${ }^{[13]}$ which suggested that balance and gait tasks may be disrupted by muscle pain, our study found no correlations between pain and balance tests in FMS patients.

The present study has some limitations that require further discussion. First of all, since our study design did not include the evaluation of the proprioception of the patients, further information regarding the relationship between this and balance along with hypermobility was not possible. Another limitation was that the patients were all middle-aged women, and the sample size of the study was small. This may have caused conflicting results that cannot be generalized to the entire population. Future studies with larger populations that involve both sexes and older FMS patients are needed. Lastly, there was the retrospective nature of the fall reporting. One strength of our study was that the patients in groups 1 and 2 did not have perceived balance problems or dizziness that could have affected the relationship between balance and hypermobility. Moreover, the participants also had similar clinical findings, except for the balance tests and Beighton scores. In addition, the presence of a control group featuring healthy subjects without hypermobility was another positive aspect of this trial.

In a recent study by Jones et al., ${ }^{[34]}$ it was reported that middle-aged FM patients have consistent objective sensory deficits on computerized dynamic posturography, and this occurseven though with normal clinical neurological examinations. Future research that objectively assesses the balance of hypermobile FM patients should highlight the relationship between hypermobility and balance in patients with FM. It can be concluded from our study results that FMS patients may have poor balance, and hypermobility may have a negative impact on balance. This situation must be considered in the clinical assessment of patients with FMS, and the patients should be informed so that necessary measures can be taken.

\section{Declaration of conflicting interests}

The authors declared no conflicts of interest with respect to the authorship and/or publication of this article.

\section{Funding}

The authors received no financial support for the research and/or authorship of this article.

\section{REFERENCES}

1. Wolfe F, Smythe HA, Yunus MB, Bennett RM, Bombardier C, Goldenberg DL, et al. The American College of Rheumatology 1990 Criteria for the Classification of Fibromyalgia. Report of the Multicenter Criteria Committee. Arthritis Rheum 1990;33:160-72.

2. Wolfe F, Ross K, Anderson J, Russell IJ, Hebert L. The prevalence and characteristics of fibromyalgia in the general population. Arthritis Rheum 1995;38:19-28.

3. Grahame R, Hakim AJ. Heritable disease and tumors of bone and connective tissue. Hypermobility syndrome. In: Hochberg MC, Silman AJ, Smolen JS, Weinblatt ME, Weisman MH, editors. Rheumatology. 4th ed. Philadelphia: Elsevier Limited; 2008. p. 2031-4.

4. Kirk JA, Ansell BM, Bywaters EG. The hypermobility syndrome. Musculoskeletal complaints associated with generalized joint hypermobility. Ann Rheum Dis 1967;26:419-25.

5. Hinman RS, Bennell KL, Metcalf BR, Crossley KM. Balance impairments in individuals with symptomatic knee osteoarthritis: a comparison with matched controls using clinical tests. Rheumatology (Oxford) 2002;41:1388-94. 
6. Sahin N, Baskent A, Cakmak A, Salli A, Ugurlu H, Berker E. Evaluation of knee proprioception and effects of proprioception exercise in patients with benign joint hypermobility syndrome. Rheumatol Int 2008;28:995-1000.

7. Galli M, Rigoldi C, Celletti C, Mainardi L, Tenore N, Albertini G, et al. Postural analysis in time and frequency domains in patients with Ehlers-Danlos syndrome. Res Dev Disabil 2011;32:322-5.

8. Ferrell WR, Tennant N, Sturrock RD, Ashton L, Creed G, Brydson $\mathrm{G}$, et al. Amelioration of symptoms by enhancement of proprioception in patients with joint hypermobility syndrome. Arthritis Rheum 2004;50:3323-8.

9. Hudson N, Fitzcharles MA, Cohen M, Starr MR, Esdaile JM. The association of soft-tissue rheumatism and hypermobility. Br J Rheumatol 1998;37:382-6.

10. Acasuso-Díaz M, Collantes-Estévez E. Joint hypermobility in patients with fibromyalgia syndrome. Arthritis Care Res 1998;11:39-42.

11. Ofluoglu D, Gunduz OH, Kul-Panza E, Guven Z. Hypermobility in women with fibromyalgia syndrome. Clin Rheumatol 2006;25:291-3.

12. Sendur OF, Gurer G, Bozbas GT. The frequency of hypermobility and its relationship with clinical findings of fibromyalgia patients. Clin Rheumatol 2007;26:485-7.

13. Jones KD, Horak FB, Winters-Stone K, Irvine JM, Bennett RM. Fibromyalgia is associated with impaired balance and falls. J Clin Rheumatol 2009;15:16-21.

14. Carlsson AM. Assessment of chronic pain. I. Aspects of the reliability and validity of the visual analogue scale. Pain 1983;16:87-101.

15. Burckhardt CS, Clark SR, Bennett RM. The fibromyalgia impact questionnaire: development and validation. J Rheumatol 1991;18:728-33.

16. Sarmer S, Ergin S, Yavuzer G. The validity and reliability of the Turkish version of the Fibromyalgia Impact Questionnaire. Rheumatol Int 2000;20:9-12.

17. Rejeski WJ, Ettinger WH Jr, Schumaker S, James P, Burns R, Elam JT. Assessing performance-related disability in patients with knee osteoarthritis. Osteoarthritis Cartilage 1995;3:157-67.

18. Ekvall Hansson E, Månsson NO, Ringsberg KA, Håkansson A. Dizziness among patients with whiplashassociated disorder: a randomized controlled trial. J Rehabil Med 2006;38:387-90.

19. Bohannon RW, Larkin PA, Cook AC, Gear J, Singer J. Decrease in timed balance test scores with aging. Phys Ther 1984;64:1067-70.
20. Sahin F, Yilmaz F, Ozmaden A, Kotevolu N, Sahin T, Kuran B. Reliability and validity of the Turkish version of the Berg Balance Scale. J Geriatr Phys Ther 2008;31:32-7.

21. Shumway-Cook A, Baldwin M, Polissar NL, Gruber W. Predicting the probability for falls in communitydwelling older adults. Phys Ther 1997;77:812-9.

22. Beighton P, Solomon L, Soskolne CL. Articular mobility in an African population. Ann Rheum Dis 1973;32:413-8.

23. Boyle KL, Witt P, Riegger-Krugh C. Intrarater and Interrater Reliability of the Beighton and Horan Joint Mobility Index. J Athl Train 2003;38:281-285.

24. Bennett RM, Jones J, Turk DC, Russell IJ, Matallana L. An internet survey of 2,596 people with fibromyalgia. BMC Musculoskelet Disord 2007;8:27.

25. Katz R, Ferbert S, Leavitt F. Fibromyalgia patients report many symptoms other than pain and fatigue. Arthritis Rheum 2007;56(Suppl 9):1532.

26. Booshanam DS, Cherian B, Joseph CP, Mathew J, Thomas R. Evaluation of posture and pain in persons with benign joint hypermobility syndrome. Rheumatol Int 2011;31:1561-5.

27. Russek LN, Fulk GD. Pilot study assessing balance in women with fibromyalgia syndrome. Physiother Theory Pract 2009;25:555-65.

28. Perell KL, Nelson A, Goldman RL, Luther SL, PrietoLewis N, Rubenstein LZ. Fall risk assessment measures: an analytic review. J Gerontol A Biol Sci Med Sci 2001;56:M761-6.

29. Tinetti ME, Baker DI, McAvay G, Claus EB, Garrett P, Gottschalk $\mathrm{M}$, et al. A multifactorial intervention to reduce the risk of falling among elderly people living in the community. N Engl J Med 1994;331:821-7.

30. Hornbrook MC, Stevens VJ, Wingfield DJ, Hollis JF, Greenlick MR, Ory MG. Preventing falls among community-dwelling older persons: results from a randomized trial. Gerontologist 1994;34:16-23.

31. Blake AJ, Morgan K, Bendall MJ, Dallosso H, Ebrahim SB, Arie $\mathrm{TH}$, et al. Falls by elderly people at home: prevalence and associated factors. Age Ageing 1988;17:365-72.

32. Hollman JH, Kovash FM, Kubik JJ, Linbo RA. Age-related differences in spatiotemporal markers of gait stability during dual task walking. Gait Posture 2007;26:113-9.

33. Harding V, Grahame R. The frequency of joint hypermobility syndrome in chronic pain patients. Pain 1990;5(Suppl.):S500.

34. Jones KD, King LA, Mist SD, Bennett RM, Horak FB. Postural control deficits in people with fibromyalgia: a pilot study. Arthritis Res Ther 2011;13:R127. 